American Journal of Animal and Veterinary Sciences 6 (4): 176-179, 2011

ISSN 1557-4555

(C) 2011 S.M. Kazemi et al., This open access article is distributed under a Creative Commons Attribution

(CC-BY) 3.0 license

\title{
Study and Identification of Insulin-Like Growth Factor-I Gene Polymorphisms in Zel Sheep Population
}

\author{
${ }^{1}$ Seyed Mohsen Kazemi, ${ }^{2}$ Cyrus Amirinia, \\ ${ }^{2}$ Hossein Emrani and ${ }^{1}$ Shahaboddin Gharahveysi \\ ${ }^{1}$ Department of Animal Science, \\ Islamic Azad University, Qaemshahr Branch. Qaemshahr, Iran \\ ${ }^{2}$ Department of Animal Biotechnology, \\ Animal Science Research Institute of Iran, Karaj, Iran
}

\begin{abstract}
Problem statement: The IGFs play an important role in regulating somatic growth according to nutritional conditions. Polymorphisms of IGF gene are reported to be significantly associated with many traits. Approach: In these study 142 samples of DNA from Zel sheep were used for detecting the polymorphisms of promoter region of the Insulin-like Growth Factor-1 (IGF-1) gene. Therefore DNA extracted from blood using Salting-out procedure. Results: Primers were supplied for amplifying the specific segment. Polymerase Chain Reaction (PCR) accomplished after finding the best condition to do the reaction. The specific segment amplified well. SSCP and RFLP markers were used for detecting the polymorphisms of the segment. For SSCP analysis PCR-product was denatured and dilution was loaded onto a $12 \%$ polyacrylamide gel. RFLP analysis was performed by incubating of PCR product by HaeII restriction enzyme at $37^{\circ} \mathrm{C}$ for $4 \mathrm{~h}$. Gels were visualized using a $3.5 \%$ agarose gel that contained ethidium bromide. The polymorphisms were the same when both methods were examined. Evaluation of result revealed 2 alleles and 3 genotypes. The alleles were $\mathrm{A}$ and $\mathrm{B}$ and their frequencies was 0.71 and 0.29 respectively. The genotyped named $\mathrm{AA}, \mathrm{AB}$ and $\mathrm{BB}$ with the frequencies of $0.47,0.47$ and 0.06 respectively. Conclusion/Recommendations: The data were analyzed for Genetic variation statistics using PopGene32 software and no deviation from Hardy-Weinberg equilibrium was observed in this study. finding the relation between genotype which is found by genetic markers with growth traits, live weight and carcass weight will be investigate by the IGFs genes.
\end{abstract}

Key words: Zel sheep, IGF-1 gene, polymorphism, RFLP, SSCP

\section{INTRODUCTION}

The Insulin-like Growth Factors (IGF-1 and 2) were discovered as skeletal growth factors produced in the liver that appeared to mediate the effects of the pituitary on whole-body somatic growth (Daughaday and Salmon, 1999). It had been shown that in addition to production in the liver, both IGF-1 and IGF-2 were produced in most, if not all, tissues.

The liver has however been confirmed as by far the main source of the large amount of IGF found in the circulation and it became increasingly apparent that pituitary Growth Hormone $(\mathrm{GH})$ was not the only regulator but that they were also very strongly nutritionally dependent. Nutrition has many interacting effects upon the IGF system, including direct effects of certain nutrients upon hepatic expression and indirect effects via insulin and via changes in hepatic GH receptors (Ketelslegers et al., 1995). The IGFs play an important role in regulating somatic growth according Corresponding Author: Cyrus Amirinia, Department of Animal to nutritional conditions. It has also become apparent that this forms part of a very fundamental control, ensuring that the development of the organism proceeds appropriately to the nutritional supply. This control system has been conserved throughout evolution from yeast to higher mammals.

Insulin-like Growth Factor (IGF) plays an important role in lactation and is involved in a variety of physiological processes including reproduction, fetal development and growth (Adam et al., 2000; Shen et al., 2003). IGF1 gene is also considered to be a factor that regulates growth, differentiation and the maintenance of differentiated function in numerous tissues and in specific cell types of mammals through binding to a family of specific membrane-associated glycoprotein receptors (Werner et al., 1994).

The objectives of this study were to search for the same polymorphisms in sheep that was found by Yilmaz et al. (2005) analyze the 5' flanking region of Biotechnology, Animal Science Research Institute of Iran, Karaj, Iran 176 
American J. Animal \& Vet. Sci., 6 (4): 176-179, 2011

the sheep IGF-I gene that could be used for determining the relationship between polymorphisms of the gene with productive and reproductive traits in future. Detecting the relation between increasing weight in different ages and also researching in Zel sheep in order to improve growth traits, live weight and carcass weight can be investigated.

\section{MATERIALS AND METHODS}

Blood samples were collected from 142 Zel sheep in Shirang breeding station located at Mazandaran province, northern Iran. Genomic DNA was extracted from blood samples in the biotechnology lab at Animal Science Research Institute (ASRI).

Detection of IGF-1 gene polymorphisms was carried out according to Yilmaz et al. (2005), the 265bp fragment of the promoter region of IGF-1 gene, 467732 bp upstream from the 5' end of Exon 1 (GenBank ID: AF492765).

Sequences of primers that were used to do the analysis were reported previously (Yilmaz et al., 2005). Sequences of IGFF and IGFR were 5'CCCCGTCCGTCGAAACATTA- 3 ' and 5'TCACATCTGCTAATACACCTTACCCG- 3' respectively.

PCR amplification: A $15 \mu \mathrm{L}$ reaction mixtureconsist of $1 \mathrm{X}$ reaction buffer, $3.5 \mathrm{mM} \mathrm{MgCl} 2,0.25 \mathrm{mM}$ of each primer, $200 \mathrm{mM}$ dNTPs, 1unit Taq polymerase (Gibco$\mathrm{BRL}$ ) and $100 \mathrm{ng}$ genomic DNA per reaction. thermal cycle for performing PCR initiated denaturation at $95^{\circ} \mathrm{C}$ for $2 \mathrm{~min} .31 \mathrm{cycles}$ of $45 \mathrm{sec}$ at $94^{\circ} \mathrm{C}, 30 \mathrm{~s}$ at $59^{\circ} \mathrm{C}$ as annealing temperature and $45 \mathrm{sec}$ at $72^{\circ} \mathrm{C}$ were performed, followed by an extension at $72^{\circ} \mathrm{C}$ for $5 \mathrm{~min}$ in a DNA Thermal Cycler.

To perform RFLP analysis, a mixture of $4 \mu \mathrm{L}$ of PCR product, $4.6 \mu \mathrm{L}$ of distilled water, $1 \mu \mathrm{L}$ of enzyme buffer and $0.3 \mu \mathrm{L}$ of enzyme incubated at $37^{\circ} \mathrm{C}$ for $4 \mathrm{~h}$. After enzymatic digestion with HaeII, gels were visualized using a $3.5 \%$ agarose gel that contained ethidium bromide.

SSCP analysis was accomplished by denaturation PCR product and loading it in polyacrilamide gel. A mixture of $10 \mathrm{~mL}$ PCR product, $8 \mathrm{~mL}$ of loading buffer and $14 \mathrm{ml}$ of ddH2O prepared and denatured for $5 \mathrm{~min}$ at $95^{\circ} \mathrm{C}$ and immediately plunged at ice for $5 \mathrm{~min} 30$ $\mathrm{mL}$ of this mixture loaded at $12 \%$ polyacrilamid gel and runned for $24 \mathrm{~h}$ at $250 \mathrm{v}$ and $4{ }^{\circ} \mathrm{C}$.

\section{RESULTS}

A 265 bp fragment from exon1 of the ovine IGF1 gene was amplified (Fig. 1). A total of 142 sheep were genotyped and three different kinds of bands were observed when two different kinds of markers were used to detect the polymorphisms.

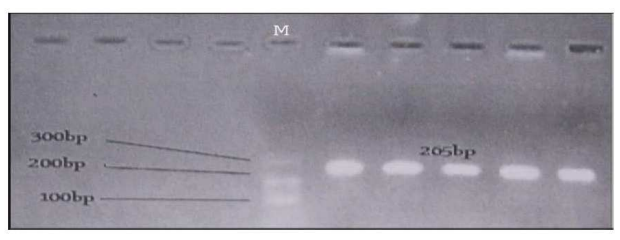

Fig. 1:PCR products analyzed by Electrophoresis in a 1 $\%$ agarose gelwith ethidium bromide staining ( $\mathrm{M}=$ Size marker $)$

At first Ge et al. (1997) has reported the C/T transition at position -472 in the 5'-noncoding region of the IGF1 gene in Angus cattle and also similar results were reported by Ge et al. (2001) and Mehmannavaz et al. (2010) in cattle using RFLP/SnaBI. It was confirmed by Yilmaz et al. (2005) using SSCP, RFLP and Tahmoorespur et al. (2009) using SSCP in sheep when detecting the polymorphisms purposed. Yilmaz has identified two single nucleotide polymorphisms; $\mathrm{A}$ and $\mathrm{T}$ to $\mathrm{C}$ transition and a $\mathrm{G}$ to $\mathrm{C}$ transversion at positions 179 and 181, respectively, of the amplified PCR product that were digested separately and resulting in recognition sites for Bsp143II and HaeI enzymes. This research is the first extensive investigation of detecting the polymorphisms in Iranian sheep breed and second in the world that concluded to the result with the restriction fragments length polymorphisms. Two alleles and three kinds of genotypes (three different patterns of bands) were observed when SSCP (Fig. 3) and RFLP markers performed to detect the polymorphisms of exon1 IGF-I and It is confirmed that the polymorphisms were the same when two different kinds of markers investigated.

\section{DISCUSSION}

In this research the mutation is at position $533 \mathrm{bp}$ upstream from the ATG codon. The $\mathrm{C}$ to $\mathrm{T}$ substitution creates a HaeII restriction site and digestion of the 265 bp PCR product with the restriction HaeII nuclease resulted in two DNA bands (179 and $86 \mathrm{bp})$ for homozygote (AA) and three bands (265, 179 and $86 \mathrm{bp})$ for the heterozygote. The DNA amplified from homozygous (BB) animals remained undigested with HaeII restriction endonuclease (Fig. 2). The observed and expected genotypic and allelic frequencies of IGF-1 gene polymorphisms has been shown in Table 1. Almost the expected genotype frequencies were similar to Tahmoorespur et al. (2009). This result suggested that genotype distribution was in the Hardy-Weinberg equilibrium ( $\mathrm{p}<0.01)$, such as Yilmaz et al. (2005). 
American J. Animal \& Vet. Sci., 6 (4): 176-179, 2011

\begin{tabular}{|c|c|c|c|c|c|c|c|c|c|}
\hline Genotypes & Number of animals & Exp. (E) & Obs, (E) & $(\mathrm{O}-\mathrm{E})^{2} / \mathrm{E}$ & $\mathrm{DF}$ & $\mathrm{XT}^{2}$ & XT2 & $\mathrm{GT}^{2}$ & Probability \\
\hline AA & 67 & 71.0 & 0.47 & 0.2281 & & & & & \\
\hline & & 247.0 & & & 1 & 2.674 & 0.1019 & 2.813 & 0.093 \\
\hline AA & 67 & 58.9 & 0.47 & 1.0991 & & & & & \\
\hline BB & 67 & $\begin{array}{r}505.0 \\
12.0 \\
247.0\end{array}$ & 0.06 & 1.3471 & & 290.000 & 81.0000 & 841.000 & 454.000 \\
\hline
\end{tabular}

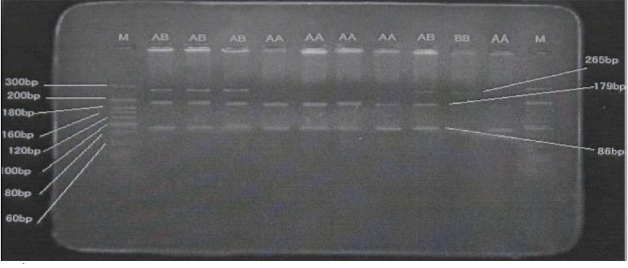

Fig. 2: HaeII digestion of PCR products using IGFF and IGFR primers and genomic DNA from animals those were genotyped. Agarose gel (3.5\%) electrophoresis showing RFLP-HaeII in 5'flanking region of the ovine IGF-1 gene. AA = 179 and $86 \mathrm{bp}, \mathrm{AB}=265,179$ and $86 \mathrm{bp}$ and finally $\mathrm{BB}=265 \mathrm{bp} . \mathrm{M}=20 \mathrm{bp}$ DNA marker

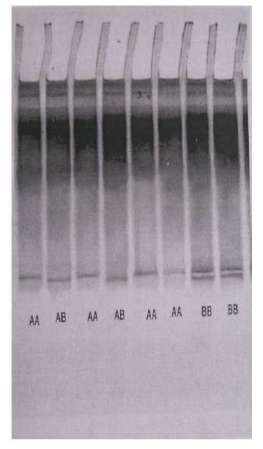

Fig. 3: Polyacrilamide gel (12\%) electrophoresisfor detection the Single Nucleotide Polymorphism (SNP) as SSCP, confirmed the same polymorphisms asRFLP/HeaII

The number of animals that represent these genotypes were 67 for both patterns $\mathrm{AA}$ and $\mathrm{AB}$ and 8 for pattern BB (Table 1).

\section{CONCLUSION}

Insulin-like Growth Factor I (IGF-I) is a hormonelike polypeptide related to several economically important traits including growth and reproduction in cattle (Spicer and Chamberlain, 1998). Although some experiments show that normal growth can be maintained even if circulating IGF-I levels are less than normal, these experiments do not rule out the importance of circulating IGF-1 as a regulator of growth hormone concentration and its correlation with local IGF-1 production in several tissues(Yakar et al., 1999). Locally produced IGF-I is more important than circulating IGF-1 in maintaining tissue growth and development (Yakar et al., 1999). However, IGF-I receptors have been detected throughout the body and IGF-I deficiency is associated with growth abnormalities in cattle (Kitagawa et al., 2001). Several studies have shown a close association between male reproductive traits and IGF-I measurements (Glander $e t$ al., 1996; Vickers et al., 1999). Mehmannavaz et al. (2010) proved a significant effect of IGF-1 polymorphism on EBVs for milk production traits on Holstein bulls. Tahmoorespur et al. (2009) found the positive influence of exon1 in average daily Gain from Birth to Weaning (GBW).

In Iran, finding the relation between genotype which is found by genetic markers with growth traits, live weight and carcass weight will be investigate in animals, especially in sheep. Also since there are many breeds of sheep that they are different genetically and phenotypically, it is suggested that other location of the IGF-1 gene and its promoter would be investigated.

\section{ACKNOWLEDGEMENT}

This research was supported by the Animal Science Research Institute (ASRI) Iran-Karaj.

\section{REFERENCES}

Adam, C.L., T.S. Gadd, P.A. Findlay and D.C. Wathes, 2000. IGF-I stimulation of luteinizing hormone secretion, IGF-binding proteins (IGFBPs) and expression of mRNAs for IGFs, IGF receptors and IGFBPs in the ovine pituitary gland. J. Endocrinol., 166, 247-254. DOI: 10.1677/joe.0.1660247

Daughaday, W.H. and W.D. Salmon, 1999. The origins and development of the somatomedin hypothesis. In: Contemporary Endocrinology: The IGF System, Rosenfeld, R. and Roberts (Eds.). Humana Press Inc., Totowa, NJ, pp: 1-15. 
Ge, W., M.E. Davis and H.C. Hines, 1997. Two SSCP alleles detected in the 5'-flanking region of bovine IGF1 gene. Anim. Genet., 28: 155-156.

Ge, W., M.E. Davis, H.C. Hines, K.M. Irvin and R.C. Simmen, 2001. Association of a genetic marker with blood serum insulin-like growth factor-I concentration and growth traits in Angus cattle. J. Anim. Sci., 79: 1757-1762.

Glander, H.J., J. Kratzsch, C. Weisbrich and G. Birkenmeier, 1996. Insulin-like growth factor-I and $\alpha_{2}$-macroglobulin in seminal plasma correlate with semen quality. Hum. Reprod., 11: 2454-2460.

Ketelslegers, J.M., D. Maiter, M. Maes, L.E. Underwood and J.P. Thissen, 1995. Nutritional regulation of insulin-like growth factor-I. Metabolism 44(suppl 4), pp: 50-57.

Kitagawa, H., K. Kitoh, T. Ito, Y. Ohba and N. Nishii et al., 2001. Serum growth hormone and insulin-like growth factor-1 concentrations in Japanese black cattle with growth retardation. J. Vet. Med. Sci., 63: 167-170. DOI: 10.1292/jvms.63.167

Mehmannavaz, Y., C. Amirinia, M. Bonyadi and R. Vaez Torshizi, 2010. Association of IGF-1 gene polymorphism with milk production traits and paternal genetic trends in Iranian Holstein bulls. Afr. J. Microbiol. Res., 4: 110-114.

Shen, W., P. Wisniowski, L. Ahmed, D.W. Boyle and S.C. Denne et al., 2003. Protein anabolic effects of insulin and IGF-I in the ovine fetus. Am. J. Physiol. Endocrinol. Metab., 284: 48-56.
Spicer, L.J. and C.S. Chamberlain, 1998. Influence of cortisol on insulin-and insulin-likegrowth factor 1 (IGF-1)-induced steroid production and on IGF-1 receptors in cultured bovine granulosa cells and thecal cells. Endocrine, 9: 153-161. PMID: 9867249

Tahmoorespur, M., M.V. Valeh, M.R. Nassiry, A. Heravi Moussavi and M. Ansary, 2009. Association of the polymorphism in the 5' flanking region of the ovine IGF-I gene with growth traits in the Baluchi sheep. S Afr. J. Anim. Sci., 39: 97-101.

Vickers, M.H., P.J. Casey, Z.J. Champion, C.G. Gravance and B.H. Breier, 1999. IGF-I treatment increases motility and improves morphology of immature spermatozoa in the GH-deficient dwarf (dw/dw) rat. Growth Horm. IGF Res., 9: 236-240.

Werner, H., M. Adamo, C.T. Roberts Jr. and D.L. Eroith, 1994. Molecular and cellular aspects of insulin-like growth factor action. Vitamins Hormones, 48: 1-58.

Yakar, S., J.L. Liu, B. Stannard, A. Butler and D. Accili et al., 1999. Normal growth and development in the absence of hepatic insulin-like growth factor I. Proc. Natl. Acad. Sci. U.S.A., 96: 7324-7329. DOI: 10.1073/pnas.96.13.7324

Yilmaz, A., M.E. Davis, H.C. Hines and H. Chung, 2005. Detection of two nucleotide substitutions and putative promoters in the 5' flanking region of the ovine IGF-I gene. J. Appl. Genet, 46: 307-309. 